\title{
Party Patronage and Politicization of the West German Administrative Elite 1970-1987 - Toward Hybridization?
}

\author{
RENATE MAYNTZ AND HANS-ULRICH DERLIEN
}

\section{INTRODUCTION}

Executive control of the bureaucracy is a perennial problem in theory as well as in practice. Enlarging the number of leadership positions, for instance by creating the office of junior minister or parliamentary state secretary, has been one response to the control problem; establishing political staffs or cabinets ministeriels is another strategy to cope with the tendency of bureaucracies to become self-controlling (Mayntz and Scharpf $1975,95-100)$. But unless one resorts to the creation of a complete second control hierarchy, organizational measures to strengthen the political executive vis-à-vis the ministerial bureaucracy can only have a limited effect. Personnel policy, and particularly political patronage, is therefore often used not only to reward loyal followers, but quite consciously as a supplementary strategy of executive leadership. In fact, political patronage counts among the oldest political control devices (Eschenburg 1961).

In systems of party government, patronage normally takes on the form of party-political patronage, i.e. preferential recruitment and promotion of civil servants affiliated with the governing party (or parties). The main rationale of such political patronage is the assumption that the protégé will use the discretion he enjoys in spontaneous compliance with the explicit goals and policies of the government and the implicit expectations of the executive leadership, thus strengthening the necessarily limited effectiveness of its formal authority. It is, thus, in the context of political control throughpatronage that the question of bureaucratic politicization, which we address in this article, assumes its significance.

Bureaucratic politicization, both in the sense of a party-political recruitment of top bureaucrats and in the sense of a growing partisan political identification of civil servants, should be distinguished clearly from the performance of essentially political functions by the bureaucracy (versus the purely instrumental role of implementation agent). In Germany, and Prussia in particular, the bureaucracy already performed the political function of policy development more than 200 years ago when, from the latter part of the 18th century onward, high civil servants were

Governance: An International Journal of Policy and Administration, Vol. 2, No. 4, Oct. 1989 (pp. 384-404), (C) 1989, Research Committee on the Structure and Organization of Government of the International Political Science Association. ISSN 0952-1895 
virtually the ruling elite. But this did not mean that they considered themselves partisan in a political sense. Based on its superior education, administrative experience, and factual information, the higher civil service viewed itself as an advocate of national welfare and the driving force of what was then called progress (Gillis 1971; Rejewski 1973, 29). While the dominant position of the top bureaucracy changed with the advent of competing political and business elites in the second half of the 19th century, it continued to play a major role in policy development, at least until Hitler came to power. In this respect, Max Weber's conception of an instrumental bureaucracy, which merely implements loyally the decisions taken by the ruler (or ruling politicians), was not a description of Prussian reality, but a theoretically derived prerequisite of the ideal-type of a legalrational political order (Weber 1964, 157-67). Therefore, Robert Putnam should not have been surprised to find that the German civil servants he interviewed in 1970 hardly corresponded to the image of the "classical bureaucrat" conceived on the basis of Weber's ideal-type bureaucracy (Putnam 1975).

The - partisan or neutral - political orientation of the civil service became an issue in the second half of the 18th century and has remained one up to the present. After the constitutional reforms following the revolution of 1848, measures were taken to keep higher civil servants from active political engagement, particularly in favor of liberal and socialist ideas. But it was not neutrality or universality (Caplan 1979) that was expected of them; rather, the bureaucracy was to support the established political order and, in fact, it sided with the conservative monarchists (Morsey 1972). It was during the Weimar Republic that the norms of political neutrality and universality were explicitly appealed to both by civil servants and by the governments then in power. For civil servants, the norm of neutrality made it possible to continue in their work without feeling obliged to support actively a government (and a constitution) to which they felt no personal loyalty; the same norm then helped the government to get a recalcitrant conservative bureaucracy to implement liberal and progressive policies. The norm of civil service neutrality thus permitted cooperation despite a lack of political consensus.

When Hitler came to power, he was not content with this second best solution; he made political partisanship explicitly a condition for obtaining and retaining office (Brandt 1976, 111,129) and subjected the bureaucracy to the direct control of the National-Socialist party. In this period, it may have been the concept of an instrumental non-political function, embedded in legal-positivist thinking, that made subservience to an imposed ideology acceptable to many a civil servant.

This historical experience has had a curiously contradictory effect. On the one hand, it has made everyone conscious that it is the very neutrality 
of the instrument that - under certain constitutional circumstances - makes abuse feasible. At the same time, it has reinforced the ideal of a nonpartisan civil service after 1945, although joining a political party has remained the constitutional right of civil servants. In view of these crosscutting pressures, it is of great interest to see to what extent the top federal bureaucrats have become party-politicized during the second republic and to what extent functional politicization is reflected in their role understanding. The data derived from a study conducted by the authors in 1987, designed to replicate Robert Putnam's survey of 1970 (Putnam 1975; Aberbach, Putnam and Rockman, 1981) ${ }^{1}$ gives us the opportunity to do so.

In the following, we will analyze to what extent party-politicization has changed over these 17 years, a period which includes the government change of 1982 and thus offers something like a natural experiment for party political streamlining of the bureaucracy. We shall also analyze whether and to what extent the subjective role definition of civil servants has changed. At this point our findings touch on the hybridization thesis advanced by Aberbach, Putnam and Rockman (1981), and we shall ask whether or not the administrative elite in Bonn is in fact changing in the hypothesized direction.

\section{CHANGES IN PARTY MEMBERSHIP OF CIVIL SERVANTS}

Judging from the responses of high-ranking federal bureaucrats given in 1987 , the German civil service has become clearly politicized - in a partypolitical sense - over the past 20 years. This at least is what 86 per cent of the respondents affirm. Nor does this perception differ conspicuously between groups of different political affiliation. There is, however, a rank effect: the higher the rank the less definitively is politicization admitted, while the lowest ranking group (those below the level of subdivision head) stresses the fact of increasing politicization most emphatically (Table 1). In all rank groups, the overwhelming majority have observed the phenomenon, but those with a strong influence on personnel policy are a bit more reluctant to admit it. Parliamentary politicians who were confronted with the same statement consented to 71.2 per cent that there is a trend toward politicization in the civil service. This perception of growing politicization, however, is apparently not a recent phenomenon: in 1970, a majority of civil servants ( 55 per cent) - though a smaller group than in 1987 - agreed that politicization was happening (Table 1). The rank effect, though, was hardly visible then.

In fact, since the early 70 s the number of avowed party members among top bureaucrats has increased. Table 2 shows a time series of party membership rates for 1970, 1972, 1981 and 1987. Despite minor differences in the composition of the samples, the fact of a general increase 
TABLE 1: Perception of Politicization by Function, 1970 and 1987

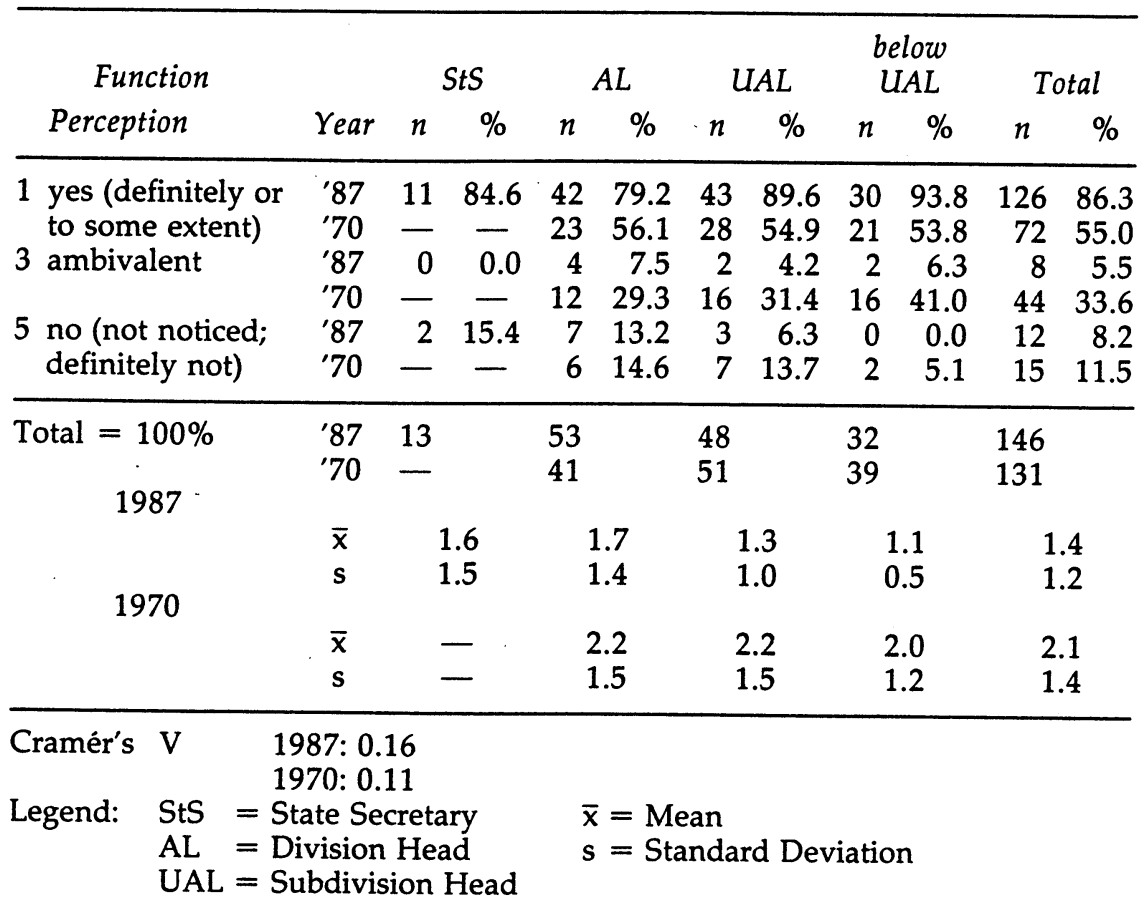

in party membership cannot be contested. In 1970 only 28 per cent of the administrative elite (without state secretaries) mentioned that they were party members. ${ }^{2}$ Two years later, in a survey putting the question more directly, the share was 48.5 per cent; the number increased to 51.7 per cent in 1981, and culminated at 57.3 per cent in 1987. Looking at those civil servants who did not declare, or explicitly denied, party membership, we recognize again a clear rank effect, but this time in the opposite direction: at all four points in time the share of non-members increases the further one moves down the hierarchy. Thus, party-related politicization is emphasized more where the proportion of party members is actually smaller.

The time series in Table 2 also reveals that members of the ruling coalition parties are generally in the majority. While in 1987 the governing Christian-Liberal coalition had 65 party members among the administrative elite, opposed to 17 Social Democrats, at all three points in time before 1982, when a Social-Liberal coalition government was in office, the majority of party members belonged to SPD and FDP. During these eleven years, the Social-Liberal coalition succeeded in increasing steadily the number of their followers in the administrative elite. In 1970, half a year after the government change of 1969, there were still relatively many CDU 
members (12 vs. 23 SPD/FDP members) in the ministerial bureaucracy; after 11 years, however, the ratio of followers to opposition party members had increased from 1.9:1 to 4.6:1. After the government change of 1982, the Christian-Liberal government managed within five years to establish a 3.8:1 relationship. Since 1970, the rank effect with regard to membership in coalition parties has become more pronounced. Opposition party members are regularly not at all found among from state secretaries; most often they occupy a rank below division head, a fact we will return to.

TABLE 2: Party Membership of Civil Servants

\begin{tabular}{|c|c|c|c|c|c|c|c|c|c|c|c|}
\hline \multicolumn{2}{|l|}{ Function } & \multicolumn{2}{|c|}{ StS } & \multicolumn{2}{|c|}{$A L$} & & $A L$ & \multicolumn{2}{|c|}{$\begin{array}{l}\text { below } \\
\text { UAL }\end{array}$} & \multicolumn{2}{|c|}{ Total } \\
\hline Party & Year & $n$ & $\%$ & $n$ & $\%$ & $n$ & $\%$ & $n$ & $\%$ & $n$ & $\%$ \\
\hline \multirow{4}{*}{$\begin{array}{l}\mathrm{CDU} / \mathrm{CSU} \\
\text { member }\end{array}$} & 1987 & 8 & 61.5 & 25 & 47.2 & 8 & 17.8 & 12 & 37.5 & 53 & 37.1 \\
\hline & 1981 & 0 & 0.0 & 4 & 8.9 & 7 & 10.0 & - & - & 11 & 9.2 \\
\hline & 1972 & 0 & 0.0 & 6 & 13.6 & 11 & 13.0 & - & - & 17 & 12.5 \\
\hline & 1970 & - & - & 4 & 10.3 & 5 & 11.1 & 3 & 7.3 & 12 & 9.6 \\
\hline \multirow{4}{*}{$\begin{array}{l}\text { SPD } \\
\text { member }\end{array}$} & 1987 & 0 & 0.0 & 4 & 7.5 & 10 & 22.2 & 3 & 9.4 & 17 & 11.9 \\
\hline & 1981 & 3 & 60.0 & 17 & 37.8 & 17 & 24.3 & - & - & 37 & 30.8 \\
\hline & 1972 & 3 & 42.9 & 11 & 25.0 & 12 & 14.1 & - & - & 26 & 19.1 \\
\hline & 1970 & - & - & 11 & 28.2 & 5 & 11.1 & 5 & 12.2 & 21 & 16.8 \\
\hline \multirow{4}{*}{$\begin{array}{l}\text { FDP } \\
\text { member }\end{array}$} & 1987 & 1 & 7.7 & 5 & 9.4 & 4 & 8.9 & 2 & 6.3 & 12 & 8.4 \\
\hline & 1981 & 0 & 0.0 & 6 & 13.3 & 8 & 11.4 & - & 一 & 14 & 11.7 \\
\hline & 1972 & 3 & 42.9 & 1 & 2.3 & 3 & 3.5 & - & - & 7 & 5.1 \\
\hline & 1970 & - & - & 0 & 0.0 & 1 & 2.2 & 1 & 2.4 & 2 & 1.6 \\
\hline \multirow[t]{4}{*}{ non-member } & 1987 & 4 & 30.8 & 19 & 35.8 & 23 & 51.1 & 15 & 46.9 & 61 & 42.7 \\
\hline & 1981 & 2 & 40.0 & 18 & 40.0 & 38 & 54.3 & - & - & 58 & 48.3 \\
\hline & 1972 & 1 & 14.3 & 26 & 59.1 & 59 & 69.4 & - & - & 70 & 51.5 \\
\hline & 1970 & - & - & 24 & 61.5 & 34 & 75.5 & 32 & 78.1 & 90 & 72.0 \\
\hline \multirow[t]{4}{*}{ Total $=100 \%$} & 1987 & 13 & & 53 & & 45 & & 32 & & 143 & \\
\hline & 1981 & 5 & & 45 & & 70 & & - & & 120 & \\
\hline & 1972 & 7 & & 44 & & 85 & & - & & 136 & \\
\hline & 1970 & & - & & 39 & & 45 & & 41 & & 125 \\
\hline
\end{tabular}

Cramér's V 1987: 0.20

1981: 0.15

1972: 0.33

1970: 0.23

No comparable data going back to the early 60 s and the 50 s are available, but such evidence as exists suggests that before 1970, party membership among top federal bureaucrats was even lower (Derlien 1985). Thus von Beyme $(1971,103)$ found that of the state secretaries in office between 1949 and 1969, only 18 per cent were members of a political party. As far as party membership of leading civil servants is concerned, 
politicization has obviously been going on for decades, increasing more sharply after 1969, when for the first time since 1949 the Social Democrats came to power as the major coalition party, and after 1982 when a conservative government took over again.

TABLE 3: Party Sympathy of Civil Servants by Party Membership

\begin{tabular}{|c|c|c|c|c|c|c|c|c|c|c|c|c|}
\hline \multirow{2}{*}{\multicolumn{2}{|c|}{$\begin{array}{c}\text { Affinity to } \\
\text { Member of Year }\end{array}$}} & \multicolumn{2}{|c|}{$C D U$} & \multicolumn{2}{|c|}{ CSU } & \multicolumn{2}{|c|}{$S P D$} & \multicolumn{2}{|c|}{$F D P$} & \multicolumn{2}{|c|}{ GRÜNE } & \multirow{2}{*}{$\begin{array}{c}\text { Total } \\
n\end{array}$} \\
\hline & & $\bar{x}$ & $s$ & $\bar{x}$ & $s$ & $\bar{x}$ & $s$ & $\bar{x}$ & $s$ & $\bar{x}$ & $s$ & \\
\hline CDU & $\begin{array}{l}' 87 \\
' 81\end{array}$ & $\begin{array}{l}3.8 \\
3.8\end{array}$ & $\begin{array}{l}0.8 \\
1.0\end{array}$ & $\begin{array}{l}2.8 \\
2.6\end{array}$ & $\begin{array}{l}1.3 \\
1.0\end{array}$ & $\begin{array}{r}0.3 \\
-1.3\end{array}$ & $\begin{array}{l}2.2 \\
1.9\end{array}$ & $\begin{array}{r}1.9 \\
-0.3\end{array}$ & $\begin{array}{l}1.8 \\
3.2\end{array}$ & $\begin{array}{l}-3.1 \\
-4.8\end{array}$ & $\begin{array}{l}1.9 \\
0.7\end{array}$ & $\begin{array}{c}44 \\
8-10\end{array}$ \\
\hline CSU & $\begin{array}{l}\prime 87 \\
\prime 81\end{array}$ & 3.1 & 1.5 & 2.4 & 2.9 & $\begin{array}{r}0.8 \\
-10\end{array}$ & 1.3 & 2.1 & 0.8 & -3.2 & 1.9 & 9 \\
\hline \multirow[t]{2}{*}{ SPD } & '87 & 0.1 & 2.2 & -1.4 & 2.7 & 2.4 & 1.0 & $-\overline{0.8}$ & $\overline{2.7}$ & $\begin{array}{r}1.0 \\
-2.2\end{array}$ & $\begin{array}{l}0.0 \\
2.2\end{array}$ & $\begin{array}{c}0-1 \\
17\end{array}$ \\
\hline & '81 & -0.7 & 2.3 & -2.7 & 2.1 & 3.0 & 1.2 & 0.9 & 2.0 & -1.9 & 2.8 & $29-36$ \\
\hline \multirow[t]{2}{*}{ FDP } & $' 87$ & 1.8 & 0.8 & 0.1 & 1.5 & 0.5 & 1.6 & 3.4 & 0.7 & -1.8 & 1.5 & 10 \\
\hline & '81 & 1.0 & 2.1 & -0.9 & 2.1 & 0.1 & 2.1 & 3.4 & 1.0 & -2.7 & 2.2 & $10-14$ \\
\hline \multirow{2}{*}{$\begin{array}{l}\text { Non- } \\
\text { member }\end{array}$} & '87 & 2.5 & 1.3 & 1.0 & 1.8 & 0.9 & 1.6 & 2.1 & 1.7 & -2.2 & 2.1 & $58-59$ \\
\hline & '81 & 1.6 & 1.7 & -0.7 & 2.2 & 0.7 & 2.1 & 1.8 & 2.0 & -2.2 & 2.2 & $50-55$ \\
\hline \multirow[t]{2}{*}{ Average } & $' 87$ & 2.6 & 1.7 & 1.3 & 2.2 & 0.9 & 1.8 & 1.8 & 2.1 & -2.5 & 2.0 & 138 \\
\hline & '81 & 1.1 & 2.3 & -1.0 & 2.5 & 1.2 & 2.3 & 1.5 & 2.1 & -2.3 & 2.4 & $101-113$ \\
\hline
\end{tabular}

The resulting impression that the administrative elite is anything but non-partisan is highlighted even more if party sympathy is taken into account (Table 3 ). On a scale ranging from +5 (high sympathy) to -5 (high antipathy), the five national parties were rated by the respondents. The only party receiving an unambiguously and uniformly negative evaluation by all groups, in 1981 and 1987, are the Greens, an opposition party in the Bundestag since 1983. All other parties, which since 1966 had been variously joined in coalition governments, were - with the exception of the Bavarian-based CSU in 1981 - viewed on average with some sympathy at least by all respondents. Not surprisingly, party members tend to like their own party best. Sympathies also reflect coalition-opposition relations among parties, but as a general tendency, the political distance between members of the two major parties (CDU, SPD) appears to have decreased since 1981 and the entry of the Greens into the federal parliament.

The survey data from the early 70 s and from 1987 show strikingly that the present preponderance of members and adherents of the "bourgeois" political parties of CDU/CSU and FDP need not manifest a perennially conservative attitude of the German administrative elite. True, the sizeable group of non-members tends to feel closer to the "bourgeois" parties CDU and FDP than to the SPD. But the dominant party preferences and 
membership change with the changes in the governing majority. It may well be, therefore, that an administrative elite which basically tends to share the party preference of the social class to which it belongs by virtue of status and origin, is ideologically brought into line with changing governments by measures of personnel policy. Such measures are facilitated by the institution of "political civil servant."

\section{POLITICAL PATRONAGE}

Political civil servants, an institution which has been discussed at length elsewhere (Mayntz 1984b; Derlien 1988a), are a special category of career civil servants whom the minister can send into temporary retirement, i.e. remove from their posts at will, mostly on the ground that they hold positions where full agreement with the policies of the government of the day is essential. In the German federal bureaucracy, those who hold the rank of state secretary and ministerialdirektor (the rank immediately below; most division heads hold this rank) are political civil servants. This legal institution, which dates back to 1852 and has repeatedly served to bring the top civil service politically into line with changing governments (Derlien 1987), is a functional equivalent of making political appointments to staff and even line positions that exist in France and the US. The German political civil servants, however, are career civil servants or must at least meet the (exacting) civil service requirements, and they are not appointed by parliamentary procedure. Most move to the corresponding rank through promotion. Such promotion, however, can obviously be influenced by political criteria, instead of being based solely on seniority and/or expertise. Selective promotion and temporary retirement according to political party affiliation can, therefore, go a long way to explain both the growing percentage of party members among top civil servants and the apparently quick shifts in the political color of these memberships, especially in the two top ranks.

In fact, in a quantitative analysis of biographical data, Derlien has shown that 260 political civil servants, in total, have been temporarily retired by successive federal governments between 1949 and 1983. This means that every third state secretary ( 36 per cent) and every fifth ministerialdirektor (20 per cent) lost his office in this way. The number of such retirements has increased steeply at times when there was a significant change in the governing majority, as happened both in 1969 and in 1982. Of the state secretaries and ministerialdirektoren then in office, 41 per cent and 25 per cent, respectively, were temporarily retired in 1969/70. These figures increased to 54 per cent and 34 per cent, respectively, after the government change in 1982 (Derlien 1988a, 58). In the 20 years before the government change of 1969, ministerialdirektoren had not been temporarily retired at 
all, while this had happened to 11 state secretaries (or seven per cent of the total). If sending civil servants into temporary retirement after government changes is an indicator of politicization, politicization has increased since 1970 in this respect, too.

Since the turnover accompanying the formation of a new government includes both temporary and normal retirements and some positional shifting (redeployment) of civil servants in top positions, the new governments of 1969 and 1982 were able to fill a significant number of vacancies with incumbents of their own choice, particularly in the two topmost ranks of the federal bureaucracy. It is evident that this opportunity is used to place followers of the new governing party or parties in top positions. A comparison of the 1970 and 1987 survey data suggests that in this respect, too, "politicization" - or discrimination against followers of the opposition party (or parties) in making new appointments - may have been even stronger after 1982 than after 1969. At any rate, the combined effects of temporary retirements and promotion produced a more selectively pro-governmental civil service elite after 1982 than after 1969. However, never are all members or adherents of an opposition party sent into temporary retirement; thus, the top ranks of the federal bureaucracy (except for state secretaries) are not staffed exclusively by followers of the governing parties or independents (see again Table 2). That the opportunity of legal purging makes a difference is, incidentally, reflected in the relatively high percentage in 1987 of SPD members among subdivision heads, a category exempt from temporary retirement.

Given the fact that political civil servants occupy normal line positions and incumbents must fulfil civil service requirements, it is not surprising that about half of the vacancies after the two government changes were filled by promotion from the ranks of the departments in both periods (Table 4). Of greater interest is the existence of a sizeable group of recruits from outside public administration. When the influx of an unusually high percentage of non-career recruits into the top bureaucracy was noted after the government change of 1969 (Putnam 1975, 264; Steinkemper 1974, 30; Aberbach, Putnam and Rockman 1981, 71), this was interpreted by several observers to reflect the scarcity of SPD followers in the bureaucracy after the long period this party had remained in opposition. But as can now be seen, a 20 per cent quota of outsiders among the recruits seems to be "normal" after a change of the governing majority. Even in our 1987 survey 15 per cent of the respondents had reached their position through unorthodox careers.

Selective promotion and outside recruitment according to criteria of political party affiliation are not the only reasons for a growing percentage of party members among high civil servants. There is a growing inclination to join a political party among higher civil servants generally. This is 
TABLE 4: Modes of Staffing Vacant Political Civil Service Positions

\begin{tabular}{|c|c|c|c|c|}
\hline \multirow[b]{2}{*}{ Recruitment } & \multicolumn{2}{|c|}{$\begin{array}{l}\text { October } 1969 \\
\text { - June } 1970\end{array}$} & \multicolumn{2}{|c|}{$\begin{array}{l}\text { October } 1982 \\
\text { - June } 1983\end{array}$} \\
\hline & $n$ & $\%$ & $n$ & $\%$ \\
\hline external recruitment & 10 & 20.4 & 12 & 20.7 \\
\hline pure rotation & 3 & 6.1 & 6 & 10.3 \\
\hline promotion from within ministry & 26 & 53.1 & 26 & 44.8 \\
\hline promotion from federal agency & 1 & 2.0 & 3 & 5.2 \\
\hline recruitment from Land, local government & 6 & 12.2 & 8 & 13.8 \\
\hline re-activation & 2 & 4.1 & 1 & 1.7 \\
\hline missing values & 1 & 2.0 & 2 & 3.4 \\
\hline
\end{tabular}

reflected in the growing percentage of avowed party members especially below the level of political civil servants. While in 1970 only 25 per cent of subdivision heads, the function immediately below political civil servants, professed membership of some political party, we found 49 per cent of subdivision heads being partisan in 1987. Again, while Putnam found only 22 per cent party members at the level below subdivision head in 1970, we found 53 per cent in 1987 (Table 2). These are sizeable differences even if Putnam's figures should be objectively somewhat too low (see endnote 2). The lower ranks in the higher civil service have apparently caught up with their superiors in matters of party affiliation. ${ }^{3}$ One consequence is that the pronounced relationship between rank and party membership in the early 70 s has meanwhile weakened, though it still exists with respect to membership in the governing parties.

Whether this growing tendency to join a political party is an opportunistic reaction to the perceived career value of the correct party book or reflects genuine attitudinal change is, of course, hard to tell. The fact that, at the lowest level in our sample where selective promotion by political criteria should be less pronounced, membership in the present governing parties clearly dominates (though not quite as much as among state secretaries and division heads), can be interpreted in two different ways. It can be an indicator of opportunism if these civil servants assume the present government party will remain in power for many years, or it can be an indicator of ideological conviction if the ruling party is expected to be voted out. The fact that not many of these party memberships are recent seems to speak against simple opportunism at first sight. The average duration of party membership in the 1987 sample varies between 15 and 20 years in the different rank groups. However, the variance is extremely high and there are, indeed, a number of civil servants in the highest positions who have joined one of the presently governing parties 
only recently. It may also be significant that, apparently, members of the ruling parties are more likely to be regarded as high-fliers by their superiors.

While we have no direct measure of ideological conviction or of the meaning which party membership has for civil servants, it is significant that the level of political activism is rather low among them. Thus only one quarter (25.3 per cent) of the 1987 respondents consider themselves to be "politically active", only slightly more than in 1970 (17.1 per cent); only 7.5 per cent held some office in their party organization in 1987. Moreover, the frequency of contact with members or functionaries of one of the political parties in Bonn is, on the average, "seldom", with not much difference between members and non-members. It is, therefore, doubtful that the party membership of civil servants always reflects a deep-seated ideological commitment. The sometimes relatively low sympathy for the party one belongs to points in the same direction. At the same time it is clear that the prevalent mechanism producing political consensus between the political executive and the top bureaucracy after a change in government is temporary retirement and selective promotion rather than opportunistic turnabouts in party membership.

\section{BUREAUCRATS IN THE PROCESS OF “HYBRIDIZATION"?}

If top bureaucrats are rarely party activists, they are still distinctly political in the sense of the "political bureaucrat" who is involved in policy-making and is sensitive to the power aspects of his job and to the political preconditions of a successful promotion of initiatives (Steinkemper 1974; Putnam 1975). That in this functional sense an attitudinal politicization has occurred is revealed in the finding that by 1987 , a positive evaluation of the inevitable political side of the top civil servant's job, already quite pronounced in 1970, has grown even more (Table 5).

Also, respondents in 1987 largely (86.4 per cent) agreed that political skills are as important as expertise for a top civil servant. Not surprisingly, therefore, German federal bureaucrats in 1987 scored even a bit lower on a "technocratic" scale than their American counterparts, in spite of the latter's more extensive and more explicitly political staffing (Aberbach et al. 1989).

Does this mean that the top civil service in West Germany's executive establishment has undergone "hybridization", that amalgamation of political and administrative roles hypothesized by Aberbach, Putnam and Rockman in a trend elaboration of the comparative data from the 1970 survey (Aberbach, Putnam and Rockman 1981, 17)? At least as far as the German Federal Republic is concerned, the answer is no. Instead, data from the 1987 study reaffirm the view expressed by one of us several years 
TABLE 5: Evaluation of the Political Side of the Job, 1970 and 1987

\begin{tabular}{|c|c|c|c|}
\hline Evaluation & $\begin{array}{r}\text { Function } \\
\text { Year }\end{array}$ & $n$ & $\%$ \\
\hline 1. Likes political side of job very much & $\begin{array}{l}1987 \\
1970\end{array}$ & $\begin{array}{r}113 \\
57\end{array}$ & $\begin{array}{l}78.5 \\
45.2\end{array}$ \\
\hline 2 Likes political side with qualifications & $\begin{array}{l}1987 \\
1970\end{array}$ & $\begin{array}{l}16 \\
28\end{array}$ & $\begin{array}{l}11.1 \\
22.2\end{array}$ \\
\hline 3 Positive and negative aspects on balance & 1987 & 9 & 6.3 \\
\hline 4 Dislikes political side of job & $\begin{array}{l}1987 \\
1970\end{array}$ & $\begin{array}{l}6 \\
9\end{array}$ & $\begin{array}{r}4.4 \\
7.2 \\
7.1\end{array}$ \\
\hline Total $=100 \%$ & $\begin{array}{l}1987 \\
1970\end{array}$ & $\begin{array}{l}144 \\
126\end{array}$ & \\
\hline 1987 & $\bar{x}$ & & \\
\hline \multicolumn{4}{|l|}{1970} \\
\hline & $\bar{x}$ & & \\
\hline & $\mathbf{s}$ & & \\
\hline
\end{tabular}

Cramér's V 1987: 0.19

1970: 0.21

ago, i.e. that German politicians and bureaucrats are not only clearly distinct groups in terms of career lines, but that there is also a basic divergence of outlook between them:

To overstate the case a bit, the top bureaucrat is political in the sense of being policy- or program-oriented: he knows that his job is policy development, and he is fully aware of the power implications of this process ... The politician, on the other hand, is power-oriented rather than policy-oriented ... (Mayntz 1984a, 201).

In fact, civil servants today distinguish their role from that of politicians even more than they did in 1970 - in spite of a greater politicization in terms of party membership (see Table 6). Parliamentary politicians perceived such role differences somewhat less frequently than bureaucrats both in 1987 (62.7 per cent) and in 1970 (58.6 per cent), but they, too, emphasize the dissimilarities more in 1987 than they did 17 years ago.

Both in 1970 and in 1987, the difference emphasized most often by the bureaucratic elite is that civil servants have more expert knowledge (mentioned by 44.4 and 45.9 per cent, respectively). While the second and third ranks in the list of traits setting top bureaucrats off from politicians are occupied by different characteristics in 1970 and in 1987, they underline 
TABLE 6: Perceived Role Differences between Top Civil Servants and Politicians

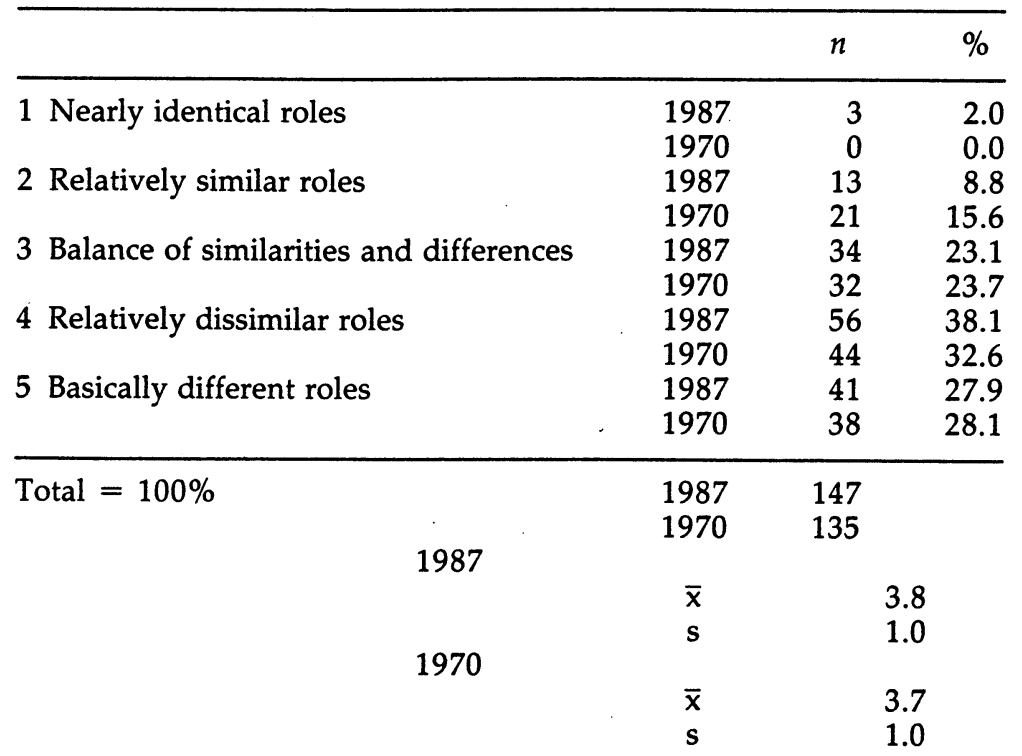

the distinctness of the administrative role at both times. Thus in 1970, responses asserting that civil servants are more pragmatically oriented occupied rank 2, while observations of the greater concern of politicians with party politics occupied rank 3 . In 1987, the corresponding rank positions were occupied by the categories "Politicians are more accountable to the public" (34.9 per cent), and "Politicians have more authority than civil servants, they direct the activities of the civil servants" (21.9 per cent). If civil servants contrast their own role with that of politicians, they apparently still tend to see it in terms of the "classical bureaucrat" model.

But this is only what sets bureaucrats off from politicians, and it is not the substantive core of their role. This is attested to by the role characteristics civil servants emphasize when considering what they have in common with politicians. In 1970 and in 1987, only two significant similarities between civil servants and politicians were perceived: that both are concerned with policy-making, and that both are tied to politics. The answers to several other questions point in the same direction. Asked to what extent they identified with a set of alternative role models, ${ }^{4}$ civil servants in 1987 identified most strongly with the "Expert with specialized knowledge for problem-solving", the "Initiator of new projects and problem solutions", and the "Implementor of political directives" (1.4 each on a four-point-scale; 1 = full agreement), rejecting most strongly the "Party politician intent to promote a specific program" and the "Advocate 
of organized interests" (3.7 each). The high agreement of the civil servants with the implementor model, incidentally, should not be misinterpreted as indicator of an incipient renaissance (or sizeable residuum) of the "classical bureaucrat" who, it is argued here, has never been so important in Germany as foreign students of Max Weber have come to think. To implement political directives is undoubtedly one aspect of the top bureaucrat's role which civil servants accept, but the implementation of laws is by no means the defining element of their role - especially not in the German Federal Republic where policy implementation is largely the task of the Iänder. The statement "A Senior Civil Servant should limit his activities to the precise application of the law" accordingly evokes a pronounced rejection (average value 3.5 on the same 4-point-scale); there has been virtually no change in the assessment of this item since 1970 (average value 3.7).

Additional support for the rejection of the "hybridization" thesis comes from the question (asked only in 1987) whether it would be acceptable for a civil servant to continue pursuing previous policy goals after a change in government, if these conflict with the new government's program. Fully 80 per cent of the respondents rejected such behavior outright, only 2 per cent finding it acceptable without qualifications. Asked what they themselves would do in the case of a conflict between explicit political directives in the government program and their own opinion on a specific matter, only 11 per cent said they would proceed immediately to implement the directives. The others would at least try to influence their political superiors to change their views, and in case of failure significant minorities would ask for redeployment (12 per cent) or even resign rather than act against their convictions (15 per cent). Even if it is an idealized response, such behavior characterizes the expert policy-maker who identifies with substantive policy conceptions rather than the politician who thrives on power games. The role perception of top civil servants that emerges from this analysis is more than ever that of the expert policy-maker, with all it takes to fulfil that function, including political loyalty and political sensitivity - the political bureaucrat still, not the "hybrid."

Finally, it should be remembered that politicians and bureaucrats are markedly distinct with respect to the profile of their activities, the arena and the communication network they operate in. While for the administrative elite in 1987 the most important activities in terms of the time spent are meetings (mentioned by 80.3 per cent), studying records (67.3 per cent), and conceptual work (61.2 per cent), the politicians' schedules display a different profile: external contacts were most often mentioned as a time-consuming activity ( 64.4 per cent), followed by meetings (62.7 per cent), constituency work (55.9 per cent), and appearance in parliament ( 50.8 per cent). 
Other changes than the rise in party membership could well be more important for the task-related behavior of top civil servants. Derlien (1988a; 1988b) has shown that several such changes have taken place: a reduction in the recruitment of the administrative elite from upper class families, a decrease in the predominance of legal studies, and a decline in the former prevalence of an uninterrupted civil service career among top bureaucrats. As far as their social background is concerned, top federal bureaucrats increasingly come from the business and professional class, and concomitantly there is a significant reduction in recruitment from higher civil service families. As for the "monopoly of jurists", the percentage of ministerialdirektoren (who constitute the vast majority of political civil servants) who had studied law has continuously decreased since 1970 (from 73 per cent in 1969 to 62 per cent in 1983), mainly in favor of economics and the sciences. Moreover, the percentage of top civil servants (state secretaries and division heads) with an uninterrupted civil service career has decreased from generation to generation and has sunk below one third in the 1923-28 birth cohort (Derlien 1988b, 26).

This greater variety in social background, education, and career experience does not mean an increased intermingling of political and administrative careers. Instead it still holds that "... for all the apparent politicization of higher civil servants, their career lines remain quite distinct from the political sector" (Mayntz 1984a, 191). This is underlined by Derlien's finding that only 15 of the 55 federal top bureaucrats (state secretaries and division heads) who were directly recruited from outside the civil service to their positions between 1949 and 1984 have come from the political sector; seven of these were state secretaries who had previously been minister in one of the Länder. If the political and the administrative elite do move closer together over time they do so neither in their task-related attitudes and role perceptions nor in their career lines, but to some extent in terms of social origin and particularly in education, both as regards level (i.e. politicians again have increasingly a university education) and preferred field of specialization (i.e. law); besides, both executive politicians and top bureaucrats do not only frequently come from civil service homes - the former often have some civil service experience in their early careers (Derlien 1988b, 27).

\section{THE PARADOX OF PARTY-POLITICIZATION}

Rejection of the "hybridization" thesis does not contradict the finding of increasing politicization. In fact, politicization is more frequently perceived in 1987 than in 1970 - a fact already visible from Table 1 - and it has become the most important aspect of the perceived change in top bureaucrats. That top bureaucrats had changed over time was affirmed 
both in 1970 and in 1987 by a vast majority of the respondents ( 91.6 and 83.5 per cent, respectively). At both times, politicization was spontaneously mentioned as one of the changes. But in 1970 this was done by only 12.7 per cent of the respondents, compared to 24.0 per cent in 1987. In 1970, the weakening of hierarchical distinctions was the change most frequently perceived (by 34.1 per cent). In 1987, the most prominent change perceived (by 24.8 per cent) was the increased dependence of civil servants on political parties. As this is clearly a special aspect of politicization, politicization now occupies ranks 1 and 2 of the changes perceived to have taken place.

Looking more closely at the answers in the category "increasing dependence on political parties", it becomes evident that civil servants ascribe this phenomenon to the increasing party-politicization of appointments to top positions, i.e. political patronage and the interference of party headquarters in personnel decisions of the executive. This degree of dependence which politicization implies is obviously resented even by "political bureaucrats", as indicated by the strikingly negative evaluation which the tendency of party-related politicization receives from civil servants (Table 7). In the 1987 survey, 73.8 per cent of that vast majority who perceived a tendency of politicization evaluated it negatively, while a

TABLE 7 Evaluation of Politicization by Party Membership

\begin{tabular}{|c|c|c|c|c|c|c|c|c|c|c|c|}
\hline \multirow[b]{2}{*}{ Evaluation* } & \multirow[t]{2}{*}{ Party } & \multicolumn{2}{|c|}{$C D U / C S U$} & \multicolumn{2}{|c|}{$S P D$} & \multicolumn{2}{|c|}{$F D P$} & \multicolumn{2}{|c|}{$\begin{array}{c}\text { Non- } \\
\text { members }\end{array}$} & \multicolumn{2}{|c|}{ Total } \\
\hline & & $n$ & $\%$ & $n$ & $\%$ & $n$ & $\%$ & $n$ & $\%$ & & \\
\hline $\begin{array}{l}1 \text { welcome trend } \\
3 \text { indifferent } \\
5 \text { reject trend }\end{array}$ & $\begin{array}{l}1987 \\
1970 \\
1987 \\
1970 \\
1987 \\
1970\end{array}$ & $\begin{array}{r}6 \\
3 \\
10 \\
2 \\
31 \\
2\end{array}$ & $\begin{array}{l}12.8 \\
42.9 \\
21.3 \\
28.6 \\
66.0 \\
28.6\end{array}$ & $\begin{array}{l}3 \\
8 \\
4 \\
3 \\
6 \\
1\end{array}$ & $\begin{array}{r}23.1 \\
66.7 \\
30.8 \\
25.0 \\
46.2 \\
8.3\end{array}$ & $\begin{array}{l}1 \\
2 \\
4 \\
0 \\
5 \\
0\end{array}$ & $\begin{array}{r}10.0 \\
100 \\
40.0 \\
0,0 \\
50.0 \\
0.0\end{array}$ & $\begin{array}{r}0 \\
10 \\
4 \\
12 \\
48 \\
22\end{array}$ & $\begin{array}{r}0.0 \\
22.7 \\
7.7 \\
27.3 \\
92.3 \\
50.0\end{array}$ & $\begin{array}{l}10 \\
23 \\
22 \\
17 \\
90 \\
25\end{array}$ & $\begin{array}{r}8.2 \\
35.4 \\
18.0 \\
26.2 \\
73.8 \\
38.5\end{array}$ \\
\hline $\begin{array}{c}\text { Total }^{*}=100 \% \\
1987\end{array}$ & $\begin{array}{c}1987 \\
1970 \\
\bar{x} \\
s \\
\bar{x} \\
s\end{array}$ & $\begin{array}{r}47 \\
7\end{array}$ & $\begin{array}{l}7 \\
8\end{array}$ & $\begin{array}{l}13 \\
12\end{array}$ & $\begin{array}{l}.8 \\
.3\end{array}$ & $\begin{array}{r}10 \\
2\end{array}$ & $\begin{array}{l}.0 \\
.0\end{array}$ & $\begin{array}{l}52 \\
44\end{array}$ & $\begin{array}{l}3.5 \\
1.6\end{array}$ & $\begin{array}{r}122 \\
65\end{array}$ & $\begin{array}{l}1 \\
7\end{array}$ \\
\hline
\end{tabular}

Cramér's V 1987: 0.29

1970: 0.32

* Only respondents perceiving politicization 
mere 8.2 per cent welcomed it as a positive development, the rest finding both good and bad sides in it. In 1970, reactions were distinctly less negative. Not only was politicization then perceived by only half of the respondents ( 55 per cent); merely 38.5 per cent of these evaluated the tendency negatively and fully 35.4 per cent positively. This means that the politicization occurring since 1970 , in terms of increasing party membership and an increased (compared to the time before 1969) use of temporary retirement and appointment to top positions according to political criteria, is clearly seen as a negative development by the very persons experiencing it.

A closer analysis of the responses in 1970 and 1987 reveals several interesting facts. First, even party members are critical of increasing politicization. While in 1970 merely 14.3 per cent of the party members held negative evaluations, in 198760 per cent were critical about partypoliticization. Among non-members, criticism has, naturally, grown even more. There are, however, characteristic differences in the evaluation of party-politicization according to party affiliation: at both points in time, members of the CDU/CSU judged the trend overwhelmingly negative; few of them welcomed politicization (with reservations). SPD-members, in contrast, evaluated politicization quite positively in 1970 (66.7 per cent). By 1987, their evaluation, too, had become negative, though 23.1 per cent still gave a positive evaluation. The stable rejection of civil service politicization among CDU-members and the growing skeptiscism among SPD-members are underlined by a similar pattern of evaluation among parliamentary politicians of both parties. Thus, the supposition that the evaluation of party-politicization among civil servants depends above all on whether one has gained from patronage, as SPD/FDP-members possibly did in 1970 and CDU/CSU/FDP-members in 1987, does not hold true. While the skeptical attitude of Social Democrat civil servants may reflect their relative deprivation after 1982, the constant and overwhelming rejection of party-politicization among CDU/CSU-members indicates that a second factor is at work. This factor is an ideological one: SPD-members have a generally more positive view of politicization, as their party program is notoriously critical of the traditional civil service code, while the Christian Democrats defend the traditional conception including the norm of civil service neutrality. This is underlined by the finding that CDUmembers, even state secretaries, like the political aspect of their job slightly less than SPD-members. In 1970, therefore, utilitarian and ideological reasons came together to make SPD members evaluate politicization predominantly as a good thing. In 1987, the two factors worked at cross purposes for SPD affiliates, which contributed to their now predominantly negative evaluation of the perceived trend. 
However, evaluation of the politicization trend was generally more negative in 1987 in all relevant subgroups, which points to a third factor: ceteris paribus, the negative consequences of politicization, as for instance the loss of autonomy resulting from party-headquarter interference, have become prominent in the eyes of civil servants between 1970 and 1987. The apparent paradox of a parallel increase in party membership and of a critical evaluation of party-related politicization may thus find an explanation in the manifest mode of political patronage. It could also reflect the fact that many civil servants feel constrained to join a political party as a precondition of reaching top positions - an act which at the same time makes their career more dependent on changes in government than on their own task-related performance; under such conditions, party membership per se should be looked at with high ambivalence.

\section{CONCLUSION}

The top civil service of the German Federal Republic has become steadily more politicized - in terms of a growing share of party members, and of the increasing importance of party membership for recruitment to top positions. This process began in the long period of CDU/CSU-dominated governments, and accelerated after 1969. In fact, the government changes of 1969 and of 1982 set off what might be called a patronage cycle, an action - reaction process, leading to higher levels of party membership in the top bureaucracy. In 1969, the Social Democrats used the existing institution of "political civil servants" to install loyal followers into the top ranks of the ministerial bureaucracy, in an effort to redirect the orientation of the federal departments in accordance with the SPD reform program. The ensuing occupation of more and more top positions by Social Democrats in the 1970 s provoked a reactive purge by the conservativeliberal government after 1982. The new government may only have tried to undo the effects of its predecessor, but in fact it achieved a level of political patronage that surpassed the former government's share of partymembers within the bureaucratic elite.

In the course, and partly as an effect of, this process of partypoliticization, the traditional civil service norm of refraining from ostensible engagement in party politics has eroded. German civil servants could always legally join political parties, but this was regarded as a private matter; notice of party membership must not enter the personnel files, and recruitment and promotion explicitly according to party affiliation is unconstitutional. Through the 1960s, the non-partisan character of the federal civil service was still an accepted, informal norm. In fact, Robert Putnam told us that when he set out to conduct his interviews in 1970, he was advised not to ask directly about party-membership, and in spite of the 
very careful phrasing of his question, he still got a high "no answer" percentage. In 1987, we had no qualms about asking directly about party membership, and only an extremely small number of respondents (4 persons, or 2.7 per cent) refused to answer. Nor did our interviewers find their subjects particularly hesitant to answer the question. Party membership has evidently become "normal" among top civil servants. What was once a taboo has become normal practice. Throughout the period under consideration, there has been a growing acceptance of the present German party democracy, and as the incriminating post-war association of "party membership" with "Nazi" slowly faded into history, those who admitted to being party members were seen with less suspicion. Perhaps this general process of normalization has lowered former psychological barriers against joining a political party.

The greater importance of party affiliation for personnel decisions, and increasing party membership among higher civil servants has, however, not resulted in "hybridization" - the fusion of administrative and political roles and role perceptions. Despite a considerable overlap in social background, education and specialization, and civil service experience, politicians and bureaucrats still follow distinct career patterns. The two elite groups also perform distinct sets of activities, reflected in their mutual role perceptions and self-images. The specificity of the institutional settings in which the two elite groups operate contributes significantly to this distinctness of task-related role perceptions.

It does not contradict the rejection of the hybridization thesis that we found the role model of the "political bureaucrat", which Robert Putnam observed in 1970, to have become even more dominant among top administrators in Bonn in the meantime. Today, hardly anybody in the ministerial bureaucracy denies and rejects functional politicization, and as a rule, they rather like the political side of the job and regard political skills as a prerequisite for top civil service positions. But "political" here refers to the power aspects in policy development and departmental management generally, and while this implies due consideration of political party majorities and intra-party power constellations, it does not mean that the political bureaucrat himself must be partisan in a party-political sense. Increasing party membership may have contributed to the familiarity of higher civil servants with the world of politics, but it is certainly not the main reason for their growing functional politicization, which has rather to do with the needs of policy-making in a situation increasingly characterized by conflicts and constraints, both political and economic. However, the de facto concomitance of functional and party-related politicization has thrown the internal strains and contradictions inherent in the top bureaucrat's role into relief, as indicated by the noticeable ambivalence of civil servants with respect to the intrusion of politics into administration. 
While they overwhelmingly like the political side of their $j o b$, they equally overwhelmingly dislike the implications of party-related politicization, notably the interference of party headquarters in executive personnel policy.

The implications of these empirical findings for the control problem investigated in this article are similarly contradictory. The functional politicization that has occurred should facilitate control of the federal bureaucracy by the political executive. It implies a greater sensitivity of civil servants for considerations of political feasibility, and institutes a kind of political self-control of top bureaucrats through their anticipation of the reactions of the cabinet and of parliament to their policy proposals and legislative drafts. At the same time, the "political bureaucrat" remains conscious of the distinctness and professional (specialist) nature of his role, which he sees as clearly subject to political authority. Especially these latter elements might tend to get lost in a process of hybridization. Thus hybridization, if it had occurred, might well have made life more difficult for the political leadership when they seek control over the bureaucracy.

Whether increasing party membership among top bureaucrats also facilitates executive control is not so clear as might appear on first sight. Obviously, if a minister and his immediate subordinates are of the same political party, political consensus will ease the control problems of departmental leadership. But a point may well be reached where political patronage becomes counterproductive. First, the reservation of top administrative positions for government party members might discourage and demotivate politically independent civil servants. And second, if trust in the relation of an elected executive to the ministerial bureaucracy is perceived to depend on membership in the same political party, the norm of loyalty owed by any civil servant to the elected political leadership will erode. Finally, the departmental leadership stands to lose some of its control over personnel policy if party headquarters try to interfere. On balance, party-related politicization, if carried to an extreme, may merely change the method of controlling the bureaucracy rather than resolving the problem it poses to the executive.

\section{Acknowledgements}

The 1987 survey is part of the Comparative Elite Study II undertaken together with Joel Aberbach and Bert Rockman. The German study is financed by a grant of the Deutsche Forschungsgemeinschaft (De 353/2-2) and supported by the University of Bamberg and the Max-Planck-Institute für Gesellschaftsforschung Köln.

Robert Putnam's generosity in providing his 1970 data set for the replication is gratefully acknowledged. We want to thank Rudolf 
Wildenmann, Max Kaase, and the Konrad-Adenauer-Stiftung for their permission to re-analyse their elite surveys of 1972 and 1981. Last but not least, we are indebted to Margot Fälker and Hermann Groß, who worked together with us on the project, for carrying out the data analysis for this article.

\section{Notes}

1 The stratified sample on which the following analysis is based included 147 higher civil servants working in federal domestic policy departments and reached 81 per cent and 62 per cent respectively of the personnel in the two top ranks. The data for 1970 are those generated by Putnam (1975) and Aberbach, Putnam and Rockman (1981); for those of 1972 and 1981 contained in Tables 2 and 3 see Kaltefleiter and Wildenmann (1982) and Wildenmann and Kaase (1982)

2 For several reasons, Putnam's figure may well be objectively too low: (1) he had no state secretaries (the most highly politicized group) in his sample; (2) he registered a high percentage of "no answer" (11 per cent); (3) he offered his respondents the choice of only declaring themselves to be "adherents" ("Sympathisanten") of some political party. The party membership figures for 1970 we use in the tables refer to those respondents who clearly indicated party membership.

3 The surprisingly high percentage of party members in the lowest ranking group may at least in part be a methodological artefact, since this category contains many "high-fliers" whom top rank respondents identified for us. This reputational sampling may well have over-represented (government) party members.

4 The role models we used for the respondents' self-assessment are taken from Aberbach, Putnam and Rockman (1981, 86-88), who had derived them empirically.

\section{References}

Aberbach, Joel D., Robert D. Putnam and Bert A. Rockman. 1981. Bureaucrats and Politicians in Western Democracies. Cambridge, Mass.: Harvard University Press.

Aberbach, Joel D., Hans-Ulrich Derlien, Renate Mayntz and Bert A. Rockman. 1989. American and West German Federal Executives: Technocratic and Political Attitudes. International Social Science Journal (in press).

Beyme, Klaus von. 1974. Die politische Elite in der Bundesrepublik Deutschland. München: Piper.

Brandt, E., ed. 1976. Die politische Treuepflicht: Motive, Texte, Materialien. Karlsruhe, Heidelberg: C.F. Müller.

Caplan, Jane. 1979. The Imaginary Universality of Particular Interests: The "Tradition" of the Civil Service in German History. Social History 4:299-317.

Derlien, Hans-Ulrich. 1985. Politicization of the Civil Service in the Federal Republic of Germany: Facts and Fables. In The Politicization of Public Administration, ed. François Meyers. Brussels: IIAS.

1987. State and Bureaucracy in Prussia and Germany. In The State and Public Bureaucracies. A Comparative Perspective, ed. Metin Heper. New York: Greenwood. 
1988a. Repercussions of Government Change on the Career Civil Service in West Germany: The Cases of 1969 and 1982. In Governance 1:50-78.

- 1988b. Continuity and Change in the West German Executive Elite 19491984. Paper presented at ECPR workshop on Patterns of Elite Transformation. Rimini, Italy.

Eschenburg, Theodor. 1961. Ämterpatronage. Stuttgart: Schwab

Gillis, John R. 1971. The Prussian Bureaucracy in Crisis (1840-1860). Stanford, Calif.: Stanford University Press.

Kaltefleiter, Werner and Rudolf Wildenmann, eds. 1972. Eine sozialwissenschaftliche Untersuchung von Führungspositionen. Westdeutsche Führungsschicht. Mannheim: Lehrstuhl für Politikwissenschaft.

Mayntz, Renate and Fritz W. Scharpf. 1975. Policy-Making in the German Federal Bureaucracy. Amsterdam: Elsevier.

Mayntz, Renate. 1984a. German Federal Bureaucrats: A Functional Elite Between Politics and Administration. In The Role of Higher Civil Servants in Central Governments, ed. Ezra N. Suleiman. New York: Holmes \& Meier.

- 1984b. The Political Role of the Higher Civil Service in the German Federal Government. In The Higher Civil Service in Europe and Canada: Lessons for the United States, ed. Bruce L. R. Smith. Washington, D.C.: Brookings.

Morsey, Rudolf. 1972. Zur Beamtenpolitik des Reiches von Bismarck bis Brüning. In Demokratie und Verwaltung, ed. Hochschule Speyer. Berlin: Duncker \& Humblot.

Putnam, Robert D. 1975. The Political Attitudes of Senior Civil Servants in Britain, Germany, and Italy. In The Mandarins of Western Europe, ed. Mattei Dogan. New York: Wiley.

Rejewski, Harro-Jürgen. 1973. Die Pflicht zur Treue im preussischen Beamtenrecht (1850-1918). Berlin: Duncker \& Humblot.

Steinkemper, Bärbel. 1974. Klassische und politische Bürokraten in der Ministerialverwaltung der Bundesrepublik Deutschland. Köln: Carl Heymanns Verlag.

Weber, Max. 1964. Wirtschaft und Gesellschaft, 4th ed. Köln, Berlin: Kiepenheuer \& Witsch.

Wildenmann, Rudolf and Max Kaase et al. 1982. Führungsschicht in der Bundesrepublik Deutschland 1981. Mannheim: Universität. 